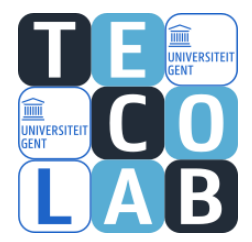

http://www.tecolab.ugent.be/publications.php

Postprint version of

Boelens, R., Voet, M., \& De Wever, B. (2018). The design of blended learning in response to student diversity in higher education: Instructors' views and use of differentiated instruction in blended learning. Computers \& Education, 120, 197-212. http://doi.org/10.1016/j.compedu.2018.02.009
Authors
Ruth Boelens:
http://www.tecolab.ugent.be/ruth.php
Michiel Voet: $\quad$ http://www.tecolab.ugent.be/michiel.php
Bram De Wever: $\quad$ http://www.tecolab.ugent.be/bram.php

Archived on biblio.ugent.be

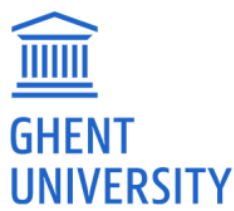

The UGent Institutional Repository is the electronic archiving and dissemination platform for all UGent research publications. Ghent University has implemented a mandate stipulating that all academic publications of UGent researchers should be deposited and archived in this repository. Except for items where current copyright restrictions apply, these papers are available in Open Access.

This item is the archived peer-reviewed author-version of:

The design of blended learning in response to student diversity in higher education: Instructors' views and use of differentiated instruction in blended learning.

Ruth Boelens, Michiel Voet, \& Bram De Wever

In: Computers and Education

DOI: http://doi.org/10.1016/j.compedu.2018.02.009

To refer to or to cite this work, please use the citation to the published version:

Boelens, R., Voet, M., \& De Wever, B. (2018). The design of blended learning in response to student diversity in higher education: Instructors' views and use of differentiated instruction in blended learning. Computers \& Education, 120, 197-212. http://doi.org/10.1016/j.compedu.2018.02.009 


\title{
The design of blended learning in response to student diversity in higher education: \\ Instructors' views and use of differentiated instruction in blended learning.
}

\begin{abstract}
The implementation of blended learning in higher education is increasing, often with the aim to offer flexibility in terms of time and place to a diverse student population. However, specific attention for the diversity of this group, and how to cater individual needs, is still scarce. Therefore, this study explores instructors' strategies for and beliefs about differentiated instruction in blended learning, together with how the differences between instructors can be explained. A total of 20 instructors working in two adult education centers participated in semi-structured interviews focusing on their (a) use of strategies for differentiated instruction, and (b) beliefs about designing blended learning to address student diversity. The findings reveal that the most commonly used differentiated instruction strategy in a blended learning context was providing students with additional support throughout product development. In addition, three instructor profiles about designing blended learning to address student diversity emerged from the data: (1) disregard: instructors considered no additional support in the blended learning arrangements to match students' needs, (2) adaptation: instructors believed that increased support in the existing blended learning arrangements was sufficient to match students' needs, and (3) transformation: instructors thought that blended learning arrangements should be designed in a completely different way, and be tailored to the characteristics of the students. The results show that half of the instructors considered a transformation of their blended learning arrangements in response to student diversity. Furthermore, instructors' beliefs appear to be strongly connected to the organization and trajectory in which they work. A major implication of these findings is that professional support focusing on instructors' beliefs is of crucial importance to unlock blended learning's full potential. As such, it is important for organizations to develop a clear stance on this issue, which pays explicit attention to responding to learners' needs in blended learning contexts.
\end{abstract}

Keywords Distributed learning environments, pedagogical issues, post-secondary education, teaching/learning strategies, blended learning. 


\section{Introduction}

Due to increasing student numbers, student populations in higher education are generally becoming more and more diverse (Fry, Ketteridge, \& Marshall, 2008). This trend has sparked a surging interest in blended learning, an instructional approach that combines online and face-to-face instructional activities (Boelens, Van Laer, De Wever, \& Elen, 2015), to create more flexible modes of education, and personalized learning trajectories (Fry et al., 2008; McKenzie et al., 2013; Wanner \& Palmer, 2015; Watson, 2008).

There are different points of view on how blended learning may contribute to achieving this goal. Traditionally, blended learning has been used to make higher education more accessible to students (Graham, Woodfield, \& Harrison, 2013), as online activities allow students to go through the learning materials when and wherever they want (Norberg, Dziuban, \& Moskal, 2011). However, more recent conceptualizations of blended learning go beyond this notion of flexibility in terms of time and place. In addition to this increased accessibility, blended learning also offers opportunities to cater students' individual needs and achieve real personalized instruction (Wanner \& Palmer, 2015; Watson, 2008). For instance, the popular flipped classroom approach to blended learning aims to free up classroom time for student questions, in-depth discussion, and personal feedback, by requiring students to prepare for learning activities online, according to their own levels of understanding (Kim, Kim, Khera, \& Getman, 2014; Wanner \& Palmer, 2015).

Unfortunately, there is not much information about how instructors in higher education actually use blended learning to provide more personalized instruction. This issue is especially important, as blended learning may help instructors to overcome a number of challenges that frequently obstruct more personalized instruction in traditional contexts, such as large classrooms or a lack of time (Nicolae, 2014; Tomlinson et al., 2003). The present study therefore examines how instructors in higher education use personalized instruction in a blended learning context, how they think about designing blended learning to address student diversity, and how possible differences between instructors may be explained. 


\section{Literature review}

\subsection{Differentiated instruction through blended learning}

As noted before, most students in higher education vary significantly in terms of interests, competences, readiness for learning, and prior (educational) experiences (Fry et al., 2008, Tomlinson \& Imbeau, 2013). As these differences matter greatly in learning (see e.g., Räisänen, Postareff, \& LindblomYlänne, 2016; Vasileva-Stojanovska, Malinovski, Vasileva, Jovevski, \& Trajkovik, 2015), personalized learning environments are key to enhancing the quality of students' learning. Such learning environments typically involve differentiated instruction, which provides different avenues to learning in relation to students' individual needs (Tomlinson \& Imbeau, 2013). Differentiated instruction can be organized on two levels. At the institutional level, student diversity is generally handled in an organizational way, often by grouping or tracking students on the basis of certain characteristics, such as their prior educational experiences (Ruys et al., 2013). At the classroom level, individual instructors modify their teaching approach to address the diverse needs of individual students in a classroom (Tomlinson et al., 2003).

Previous research in the field of differentiated instruction has mainly focused on the classroom level (see e.g., De Neve, Devos, \& Tuytens, 2015; Humphrey et al., 2006; Smit \& Humpert, 2012), and has put forward four components to describe how instructors match their classroom instruction to students' individual differences: content, process, product, and affect (Tomlinson, 2001; Tomlinson \& Imbeau, 2013). First, content is defined as the information and ideas that students need to acquire in order to reach learning goals (Tomlinson \& Imbeau, 2013). Flexibility in content can be provided in two ways: by adapting the curriculum, or what is being taught, and by modifying resources, or how the content is presented (Santangelo \& Tomlinson, 2009; Tomlinson, 2001). Second, process is understood as how students process the content and acquire new skills (Tomlinson, 2001; Tomlinson \& Imbeau, 2013). The process is generally modified by changing the level at which learning takes place, for example, by alternating between whole class instruction, flexible grouping, and individualized activities (Hall, Strangman, \& Meyer, 2003; Tomlinson, 2001). Third, product refers to how students demonstrate what they know, understand, and can do after having received instruction (Santangelo \& Tomlinson, 2009; 
Tomlinson \& Imbeau, 2013). In this respect, instructors can create varied assessment options to capture mastery of learning goals, and provide students with different forms of support throughout product development (Santangelo \& Tomlinson, 2009; Tomlinson \& Kalbfleisch, 1998). Fourth, the concept of affect can be interpreted as students' feelings about the classroom environment. The main question here is whether all students feel safe, accepted, and valued (Tomlinson \& Imbeau, 2013). Instructors can cultivate such feelings by ensuring that students interact and discuss in constructive ways, without making a person or certain part of the group feel smaller (Tomlinson, 2001).

Most of the research on differentiated instruction has been carried out in the contexts of primary and secondary education, with little attention to differentiated instruction in higher education (Santangelo \& Tomlinson, 2009). Still, this work suggests that instructors may encounter a number of challenges when organizing differentiated instruction (De Neve et al., 2015; Humphrey et al., 2006; Smit \& Humpert, 2012). Frequently cited challenges include limited human or physical resources, restrictive curricula, perceptions that organizing differentiated instruction is a time-consuming task, or a lack of skills for organizing differentiated instruction (De Neve et al., 2015; Humphrey et al., 2006; Smit \& Humpert, 2012). Blended learning can help to overcome some of these challenges. For example, it may help to free up classroom time through online preparatory activities (Kim, Kim, Khera, \& Getman, 2014; Wanner \& Palmer, 2015), or make differentiated instruction in large classrooms more manageable through online personalized activities (McKenzie et al., 2013).

Through its combination of face-to-face and online activities, blended learning thus holds great potential for organizing differentiated instruction in higher education. Unfortunately, previous research on blended learning mainly focusses on instructors' use of and perceptions about blended learning in general, rather than in relation to differentiated instruction (Bliuc, Casey, Bachfischer, Goodyear, \& Ellis, 2012; Ellis, Hughes, Weyers, \& Riding, 2009). Overall, these studies report that instructors' thinking about blended learning may vary from low-level views focused on smoothening existing learning activities, to more high-level views that are mainly concerned with meeting students' learning needs (e.g., Bliuc et al., 2012; Ellis et al., 2009; C. Kim, Kim, Lee, Spector, \& DeMeester, 2013; Voet \& De Wever, 2016b). More specifically, several studies have shown that instructors are more likely to 
focus on content delivery and meeting practical needs, rather than on student learning and providing tailored support to meet students' needs (Bliuc et al., 2012; Davies, Dean, \& Ball, 2013; Ellis et al., 2009). Even so, it is still not clear how instructors may actually envision blended learning in view of differentiated instruction, or what kind of strategies they put forward for differentiating between students. The finding that instructors' views and use of blended learning may vary also raises the question about how these differences might then be explained.

\subsection{Explaining differences between instructors}

A review of the literature on instructors' instructional decisions reveals two types of factors that may help to explain differences in instructors' use of differentiated instruction, and views of designing blended learning to address student diversity. On the one hand, several authors have argued that the individual is crucial for explaining differences between instructors (Bliuc et al., 2012; Ellis et al., 2009). It seems that what instructors do is primarily determined by their beliefs about education (Ertmer, 2005). Such beliefs are the sum of instructors' personal judgements and evaluations about education, and include, for example, ideas about effective forms of instruction and organization, or student and teacher roles (Valcke, Sang, Rots, \& Hermans, 2010). These beliefs form a mental framework for making decisions and interpreting new experiences (Goodman, 1988; Pajares, 1992), and in this way, determine instructors' classroom behavior (Ertmer, 2005; Goodman, 1988; Kagan, 1992; Kim et al., 2013; Pajares, 1992; Valcke et al., 2010; Voet \& De Wever, 2016a). This can explain why, for example, instructors who are primarily concerned with students' learning needs are more likely to design blended learning arrangements that support deep and meaningful student learning (Bliuc et al., 2012).

On the other hand, other authors instead emphasize the importance of the organization, as decisions at the institutional level also have an impact on the decisions that individual instructors make about the way they approach blended learning (González, 2012). This line of reasoning is supported by several studies that have been able to explain differences in the use of strategies for differentiated instruction based on the institutional context (De Neve et al., 2015; Smith, 2011). For instance, it appears that 
instructors are more likely to incorporate blended learning in meaningful ways if there is a clear and supportive institutional strategy, such as providing room for experimenting with blended learning (González, 2012).

To summarize, it is thus rather unclear how differences in instructors' strategies for and beliefs about differentiated instruction in blended learning might be explained. In particular, previous research raises the question to what extent differences may be explained by respectively the individual or the organization.

\subsection{The present study}

Situated against the background of a diverse student population within the context of higher education, the present study focuses on instructors' strategies for and beliefs about differentiated instruction in blended learning. In addition, it explores how differences between instructors may be explained. As such, the research questions are:

(1) What strategies do instructors put forward to differentiate between students in a blended learning context?

(2) What are instructors' beliefs about designing blended learning to address student diversity?

(3) How can differences in instructors' strategies for differentiated instruction and beliefs about designing blended learning to address student diversity be explained?

\section{Method}

\subsection{Research setting}

The present study is part of a larger research project in Flanders (Belgium), on the design of blended learning arrangements for students enrolled in a teacher training program within adult education (see Eurydice (2009) for more information about adult education in Flanders). Flanders has currently two types of teacher training: (1) the integrated teacher training, in which students follow a three-year 
program focusing on a combination of subject-specific and pedagogical courses, and (2) the specific teacher training, in which students follow a shorter program solely focusing on pedagogical courses. This study is situated in the latter type, and as such, the focus of this training primarily lies on teaching methods, as students must be qualified for a specific subject in order to enroll. In the case of general subjects, such as history, psychology or chemistry, subject qualification is associated with a higher education degree, while for vocational subjects, such as electricity, hairdressing or baking, subject qualification is associated with a degree of vocational or technical secondary education. In other words, for some students, the teacher training program is their first experience with higher education, while other students have already obtained a degree in higher education. This implies that instructors in this context are confronted with students who are highly diverse in terms of prior educational experiences.

Participants of this study were instructors working in a teacher training program in an adult education center in Flanders. Two adult education centers were contacted. These two centers differed in size and in how they organize the teacher training programs. More detailed information about the context of these centers is presented in Table 1 and the most important differences in how these centers organize the teacher training programs are further explained below.

Table 1

The teacher training program's organization across the two adult education centers.

\begin{tabular}{|c|c|c|}
\hline & Center A & Center B \\
\hline Grouping (institutional level) & Heterogeneous groups & Homogeneous groups \\
\hline $\begin{array}{l}\text { Specific teacher training } \\
\text { ( } 60 \text { credits) }\end{array}$ & $\begin{array}{l}\text { (1) E-learning with weekly face-to- } \\
\text { face meetings } \\
\text { (2) Non-modular } \\
\text { (3) Modular }\end{array}$ & $\begin{array}{l}\text { (1) For students with a degree of vocational } \\
\text { or technical secondary education } \\
\text { (2) For students with a degree of higher } \\
\text { education }\end{array}$ \\
\hline $\begin{array}{l}\text { Instructors' average } \\
\text { experience in teacher } \\
\text { education }\end{array}$ & 7.32 years $(\mathrm{SD}=5.51, \mathrm{n}=14)$ & 4.58 years $(\mathrm{SD}=1.43, \mathrm{n}=6)$ \\
\hline
\end{tabular}

First, the main difference was the allocation of student teachers to specific class groups. In center A, student teachers with secondary and higher education degrees were put together in class, while in center B, student teachers with a degree of higher education were not taking classes together with those holding a degree of vocational or technical secondary education. In other words, students in center B were 
tracked, at institutional level, in homogeneous groups based on educational background, while center A opted for heterogeneous groups.

Second, both centers offered their teacher training programs in blended learning formats. However, there were some differences in the organization of these blended learning programs. Center A offered three different trajectories, which differed in the amount of online learning. Two trajectories (i.e., the nonmodular and the e-learning trajectory) were organized in clusters, rather than in separate courses: a theory cluster, an experimentation cluster, and an experience cluster or internship. In the (1) e-learning trajectory, the theory cluster consisted of 18 online thematic modules, while the experimentation cluster consisted of maximum one weekly face-to-face meeting to integrate the theory into practice, for instance through microteaching. In the (2) non-modular trajectory, there were also face-to-face meetings for the theory cluster (with the online part being reduced to about $25 \%$ of the cluster). In contrast to the first two trajectories, the (3) modular trajectory consisted of nine individual courses, next to an internship. Each course had an online part that took up about $25 \%$ of the course. Although student teachers could freely choose between trajectories, the e-learning trajectory was especially followed by those with a higher education degree, while those with a secondary education degree mainly enrolled in the modular trajectory. In the non-modular trajectory, the group was more diverse. In center B, all trajectories consisted of individual courses and an internship. The trajectory for student teachers with a secondary education degree was similar to the modular trajectory in center A, while the trajectory for those with a higher education degree was similar to the e-learning trajectory in center A.

\subsection{Participants and data collection}

Invitations to participate in the study were sent out to all instructors working in teacher training in one of the two adult education centers. The first author contacted the instructors through email, and requested a response within two weeks. Afterwards, a reminder was send to those who had not yet responded. In center A, 15 out of 19 instructors were willing to participate, while in center B, 6 out of 7 instructors were willing to take part. In other words, the response rate was about equal in both centers, with 
respectively $79 \%$ and $86 \%$ in center A and B. Prior to data collection, all participants received an explanation of the project. Participation was voluntary and the instructors gave their informed consent for participation, having been made fully aware of the nature and purpose of the research.

Semi-structured interviews were conducted to explore instructors' strategies for differentiated instruction and beliefs about designing blended learning arrangements for students with different prior educational experiences. Qualitative approaches and indirect measures are commonly used to explore instructors' beliefs (Miles \& Huberman, 1994), and conducting interviews allowed to get a detailed understanding of individual experiences and interpretations that are of importance to the present study's research questions (Cohen, Manion, \& Morrison, 2007).

The interview protocol was organized around a set of predetermined open-ended questions, which allowed the interviewer to ask for more details or to clarify misunderstandings (Cohen et al., 2007). The protocol centered on three main themes: participants' (1) background information (e.g., age, experience in education), (2) use of strategies to differentiate between students in a blended learning context, and (3) beliefs about designing blended learning arrangements for students with different prior educational experiences. The complete protocol can be found in Appendix A.

All participants were interviewed by the first author of this study. The duration of an interview varied between 40 and 113 minutes, with an average of 69 minutes ( $S D=20)$. To avoid social desirability biases, the interviewer ensured that all participants felt comfortable and secure to talk freely during the interview (Cohen et al., 2007). To make each participant feel as comfortable as possible, the interviewer told the participants that there were no right or wrong answers, and that all data would be treated and reported confidentially.

All interviews were audio-recorded with permission from the participants, and afterwards transcribed for data analysis. Due to the bad quality of one audio recording, one interview (with an instructor of center A) could not be transcribed and analyzed. Consequently, 20 instructors remained in the study. Of these 20 participants, 14 were female and 6 were male. Participants' mean age was 41.95 years ( $\mathrm{SD}=9.58)$, and their average experience in teacher education was 6.50 years $(\mathrm{SD}=4.80)$. 


\subsection{Data analysis}

In order to analyze the qualitative data, the interview transcripts were coded using NVivo 11 (Miles \& Huberman, 1994). A predetermined coding scheme was established based on the conceptual framework and research questions described above. Units of meaning (i.e., units that could be classified into a single category) were chosen as the unit of analysis. A final coding scheme with additional (e.g., ICT support) and refined codes (Cohen et al., 2007) was obtained by re-reading the transcripts several times, and applying the initial coding scheme to eight randomly chosen transcripts. The final version of the coding scheme consisted of two parts (see Appendix B). First, the four components of differentiated instruction (content, process, product, and affect) were divided into nine subcategories, and one new category described as ICT support. One differentiated instruction strategy, the modification of curricula, was left out of the results, as it was not mentioned by the participants during the interviews. This was, however, not surprising, since the study took place in a formal setting with a fixed curriculum. Second, the coding scheme focused on identifying challenges that students can be confronted with in blended learning arrangements, together with instructors' views of how they would deal with these challenges. Emerging codes from the data were adaptation, transformation, and disregard (for details, see appendix B).

The final coding scheme was used by the first author to analyze all transcripts. To check its reliability, a second coder independently analyzed 16 transcripts. For this purpose, the independent coder was given a training, which focused on the aims and method of the study, construction of the coding scheme, and meaning of the codes. During this training, the first author and second coder jointly worked on four transcripts and openly discussed the coding strategy. This allowed the independent coder to familiarize herself with the coding scheme. Subsequently, the second coder independently analyzed the 16 remaining transcripts, and inter-rater reliability was calculated. Percent agreement for the coding of differentiated instruction strategies was $82 \%$, while that for the categorization into types of beliefs about design of blended learning was $90 \%$ (18 out of 20 cases). According to Miles \& Huberman (1994), both outcomes are considered to indicate good inter-coder agreement. Afterwards, all disparities were discussed by the two independent coders until agreement was reached. 
Finally, two matrices were compiled based on the final coding (Miles \& Huberman, 1994). The first matrix listed which strategies for differentiated instruction instructors used (see also Table 2 in section 4.1.2 strategies for differentiated instruction), while the second matrix contained an overview of participants' beliefs about the design of blended learning arrangements in answer to student diversity. Based on these two matrices, each instructor was then positioned on two axes: one included the number of differentiated instruction strategies, whereas the other contained the types of beliefs about the design of blended learning that emerged during the data analysis.

\section{Results}

In keeping with the three research questions, the results section is divided into three subsections. The first subsection provides more information about the strategies put forward by instructors to differentiate between students with a degree of vocational or technical secondary education, and those holding a degree of higher education. The second subsection then presents an overview of instructors' beliefs about how blended learning should be designed to take these differences between students into account. Finally, the third subsection links the findings of the previous two to one another, and also relates this to the organization in which instructors work. To further substantiate and illustrate the findings, each of these subsections draws on instructors' quotes (translated from Dutch to English). Instructors' names were replaced by a code, of which the letter (A-B) refers to the center where they worked, while the number (1-20) refers to their individual identification.

\subsection{Strategies for differentiated instruction in a blended learning context}

\subsubsection{Perceived differences between students}

During the interviews, instructors were asked to indicate which differences they noticed between students with a degree of vocational or technical secondary education and students with a degree of higher education, and how this was related to their teaching approach. All instructors reported that they noticed at least one difference between these two groups during their lessons. The most recurrent themes were (1) language abilities ( $\mathrm{n}=20$ ), such as writing skills, familiarity with jargon, English terms, or 
official school language, (2) ICT skills ( $n=17)$, related to using the center's learning platform, formatting or editing a Word document, sending e-mails, or communicating online, (3) competences for processing the content $(\mathrm{n}=15)$, such as identifying core information, structuring, or summarizing content, and (4) competences for monitoring one's own learning $(n=9)$, including the need for feedback and confirmation, and ability to analyze task demands. For all these themes, instructors noted that mastery of these skills was generally lower for students with a degree of vocational or technical secondary education, compared to those with a degree of higher education.

\subsubsection{Strategies for differentiated instruction}

An overview of the individual instructors' use of strategies for differentiated instruction is presented in Table 2. Of all instructors, one instructor did not report any strategy to deal with differences between students. The other 19 instructors indicated several strategies to change their instruction based on individual students' needs. The average number of reported strategies for differentiated instruction was $3.25(\mathrm{SD}=1.74)$, with a maximum of seven different strategies.

Table 3 presents these results in a different form, by focusing on the categories and strategies for differentiated instruction, rather than on the individual instructors. It provides an illustration of each strategy, and notes how often each strategy was mentioned. It turns out that instructors most frequently reported strategies for differentiated instruction on product $(n=15)$ and process $(n=13)$ level, while interventions on the affect $(\mathrm{n}=8)$ and content $(\mathrm{n}=9)$ level were reported less frequently by the instructors. Next to these four main categories, ICT support was added as an additional category. Seven instructors stated that they often needed to provide additional ICT support to students with a degree of vocational or technical secondary education. Furthermore, within these main categories, some specific strategies are implemented more often than others. The most frequently reported strategies were the provision of additional support throughout students' development of a product that shows what they have learned $(n=12)$ and strategies using whole class instruction $(n=11)$, whereas grouping strategies $(n=3)$ and individualized activities $(n=4)$ were reported far less. 
Table 2

Instructors' individual use of strategies for differentiated instruction

\begin{tabular}{|c|c|c|c|c|c|c|c|c|c|c|}
\hline \multirow{3}{*}{ Instructor } & \multicolumn{9}{|c|}{ Differentiated instruction categories ${ }^{1}$} & \multirow{3}{*}{$\begin{array}{c}\text { Total number of } \\
\text { differentiated } \\
\text { instruction } \\
\text { strategies }\end{array}$} \\
\hline & \multicolumn{2}{|c|}{ Content } & \multicolumn{3}{|c|}{ Process } & \multicolumn{2}{|c|}{ Product } & \multirow{2}{*}{$\begin{array}{c}\text { Affect } \\
\text { Climate }\end{array}$} & \multirow[b]{2}{*}{$\begin{array}{c}\text { ICT } \\
\text { support }\end{array}$} & \\
\hline & $\begin{array}{c}\text { More varied } \\
\text { teaching } \\
\text { materials }\end{array}$ & $\begin{array}{c}\text { Additional } \\
\text { support }\end{array}$ & $\begin{array}{l}\text { Whole class } \\
\text { instruction }\end{array}$ & Grouping & $\begin{array}{l}\text { Individualized } \\
\text { activities }\end{array}$ & $\begin{array}{c}\text { Additional } \\
\text { support }\end{array}$ & $\begin{array}{c}\text { Varied } \\
\text { assessment } \\
\text { options }\end{array}$ & & & \\
\hline B1 & $\checkmark$ & $\checkmark$ & $\checkmark$ & & & & $\checkmark$ & & $\checkmark$ & 5 \\
\hline B2 & & $\checkmark$ & $\checkmark$ & & $\checkmark$ & $\checkmark$ & $\checkmark$ & $\checkmark$ & & 6 \\
\hline B3 & & $\checkmark$ & $\checkmark$ & & & $\checkmark$ & $\checkmark$ & & & 4 \\
\hline B4 & & $\checkmark$ & $\checkmark$ & & & $\checkmark$ & $\checkmark$ & $\checkmark$ & & 5 \\
\hline B5 & & & & & & & $\checkmark$ & $\checkmark$ & $\checkmark$ & 3 \\
\hline B6 & & & & & & & & $\checkmark$ & $\checkmark$ & 2 \\
\hline A7 & $\checkmark$ & & $\checkmark$ & & & & & & & 2 \\
\hline A8 & & & & $\checkmark$ & & $\checkmark$ & & & & 2 \\
\hline A9 & & & $\checkmark$ & & & $\checkmark$ & $\checkmark$ & & $\checkmark$ & 4 \\
\hline A10 & $\checkmark$ & $\checkmark$ & $\checkmark$ & & & $\checkmark$ & $\checkmark$ & $\checkmark$ & $\checkmark$ & 7 \\
\hline A11 & & & $\checkmark$ & $\checkmark$ & $\checkmark$ & & & & $\checkmark$ & 4 \\
\hline A12 & & & $\checkmark$ & & & $\checkmark$ & & $\checkmark$ & & 3 \\
\hline A13 & $\checkmark$ & & & & & & & & $\checkmark$ & 2 \\
\hline A14 & & & & & & & & & & 0 \\
\hline A15 & & & & & & $\checkmark$ & & $\checkmark$ & & 2 \\
\hline A16 & $\checkmark$ & & $\checkmark$ & & & $\checkmark$ & & & & 3 \\
\hline A17 & & $\checkmark$ & & & & $\checkmark$ & $\checkmark$ & & & 3 \\
\hline A18 & & & $\checkmark$ & $\checkmark$ & $\checkmark$ & $\checkmark$ & & $\checkmark$ & & 5 \\
\hline A19 & & & & & $\checkmark$ & $\checkmark$ & & & & 2 \\
\hline A20 & & & & & & & $\checkmark$ & & & 1 \\
\hline
\end{tabular}


An overview of the strategies for differentiated instruction, together with an illustration and instructors' use of them

\begin{tabular}{ll}
\hline $\begin{array}{l}\text { Differentiated instruction } \\
\text { categories }^{1}\end{array}$ & Illustration \\
\hline
\end{tabular}

\section{Content}

1.a. Provide varied teaching materials

"I make a distinction between basic subject matter and additional subject matter, or provide students with additional video fragments, tools and quizzes to exercise, so that students can choose which materials they want to use to process subject matter (instructor A10)."

1.b. Provide additional support in "I integrate pictograms in the learning material to show students what is important, less important, a problem statement, or an exercise teaching materials (instructor B1)."

\section{Process}

2.a. Whole class instruction

"During my face-to-face lessons for students with a degree of higher education I do not really follow the course manual when I am teaching, while during my lessons for students with a degree of vocational or technical secondary education, I use the course manual as a guide and I stick to that course content (instructor B4)."

"Students have to make an assignment in heterogeneous groups. They need to present their group product to the whole class and the

2.b. Grouping

whole class can react to their product. In this way, they are confronted with the diversity in the group, and everyone is challenged to do something more than he or she already could (instructor A8)."

"Students could choose between several topics in some of the distance assignments: on the one hand we offered new, additional topics

2.c. Individualized activities

that were not discussed in class, and on the other hand we offered topics that were extensions from the content provided during the lessons (instructor A19)."

\section{Product}

3.a. Provide additional support throughout product development

3.b. Provide varied assessment options

"When students need to write a reflection, I provide them with different instructions. For learners with a higher education degree I give one open question and say: 'this is the maximum number of words'. For learners with a degree of secondary education, I divide the assignment into smaller parts and ask them to respond to multiple specific questions (instructor B2)."

"Students have the choice to make a digital brochure or another product instead of a paper since this focuses less on learners' writing skills (instructors B3, A17)."

"I often say to students with a degree of vocational or technical secondary education that they will be very important teachers. I try to create little success experiences, and help them to believe in their own successes (instructor B4)."

"After a face-to-face meeting, or during breaks, I show them how Moodle works, or how to format documents. I give them the space to

5. ICT support grow and learn. For the first assignment, they may submit a flat, unformatted Word document, and then I provide some brief feedback on how they can format and edit the Word document (instructor A9)."

${ }^{1}$ Based on Lawrence-Brown (2004), Tomlinson \& Imbeau (2013), Tomlinson \& Kalbfleisch (1998), Tomlinson et al. (2003), and Tomlinson (2001), Santangelo \& Tomlinson (2009) 


\subsection{Beliefs about designing blended learning to address student diversity}

Even though blended learning may help to provide differentiated instruction, instructors commonly pointed out that blended learning may also give rise to additional challenges for some students. After discussing these challenges, this section introduces three distinct profiles related to the design of blended learning arrangements for this specific student group, which emerged from our interviews.

Eighteen of the instructors indicated that blended learning programs are often more challenging for students with a degree of vocational or technical secondary education, compared to those holding a degree of higher education. Only two instructors (A8, A20) did not see challenges for this specific student group. The three most recurrent challenges in instructors' answers were that students with a degree of vocational or technical secondary education (1) experience more problems with technology $(n=8),(2)$ are not used to independently acquiring and processing content $(n=10)$, and (3) have more trouble with meeting deadlines $(n=3)$.

Based on the interview responses, three profiles could be discerned regarding instructors' beliefs about the design of blended learning arrangements for students with a degree of vocational or technical secondary education. First, four instructors' answers corresponded with a disregard profile, since they offered no specific ideas about how to design blended learning arrangements to meet the needs of these students. Second, six instructors had an adaptation profile. They argued that their existing blended learning arrangements need increased or adapted support to better match the needs of students with a degree of vocational or technical secondary education. Third, 10 instructors had a transformation profile. These instructors believed that more profound changes were needed, and that blended learning arrangements for students with a degree of vocational or technical secondary education should be designed in a totally different way than blended learning arrangements for students with a degree of higher education.

\subsubsection{Disregard}

This profile had two different interpretations. First, two instructors (A8, A20) did not report any challenges for students with a degree of vocational or technical secondary education, and logically 
expressed no modifications in their design of blended learning. Second, two instructors (A9, A7) reported challenges for students with a degree of vocational or technical secondary education, but no concrete modifications in their design of blended learning. For instance, instructor A7 was not convinced that blended learning was an appropriate approach for this group, but then also did not offer any solutions. Instead, he stated that: "My story is that blended or distance education brings a lot of stress for low-educated learners, while for high-educated learners it is a relief in many ways."

\subsubsection{Adaptation}

Six instructors indicated several actions to provide more guidance and support to students with a degree of vocational or technical secondary education in their existing blended learning arrangement, but did not explicitly state that the whole design a blended learning course should be changed. The most frequently reported actions were: (1) the provision of a guidebook or concrete guidelines to communicate expectations (instructors B6, A18), (2) the provision of clear guidelines about the learning platform, including instructions on where to post assignments or where students can find their feedback (instructors B6, A17, A18), (3) following up individual students to remind them of deadlines (instructors B6, A12, A18, A19), (4) giving students opportunities to send a draft version of an assignment before the final version (instructors A18, A19), and (5) building in monthly supervision between (individual) students and the instructor about the content of the course and students' learning process (instructors A14, A19). Other actions were: personalizing the structure (i.e., ill-structured vs. structured) of assignments (instructor A14), replace English texts (instructor A18), provide a manual or guidebook when students need to watch videos (instructor A18), be accessible as instructor, for instance, by responding to emails every two days (instructor A18), offer variation in online exercises (instructor A17), and provide both online and face-to-face opportunities for interaction (instructor A17).

\subsubsection{Transformation}

Ten instructors remarked that the blend should not be the same for students with a degree of vocational or technical secondary education, and students with a degree of higher education. Depending on the student group, they proposed to design instructional activities in a totally different way, or provide other 
kinds of blends. Yet, at least eight of them (B1, B3, B4, B5, A11, A13 A15, A16) also emphasized that the instructor will always play a central role in students' learning of the content (during face-to-face meetings). For instance, instructor A11 explained that: "Blended learning needs to take place in another way, and the instructor will always play a central role in the introduction of theories. We need to provide other kinds of blends, for example [one that combines] a preparatory assignment outside the classroom, a face-to-face moment to explain and interpret the theory, and an online assignment to deal with the theory." Often, these instructors additionally reported several smaller adjustments that were also mentioned by instructors with an adaptation profile, such as: the provision of direct and individual feedback (instructors B2, B4, A15), scaffolding students' self-regulatory skills (instructors B3, A16), or the provision of a clear structure, expectations, and an overview of the deadlines and assignments (instructors B4, B5, A11).

\subsection{Explaining differences between instructors}

To shed more light on the extent to which individual factors may explain differences between instructors, Figure 1 plots their repertoire of strategies for differentiated instruction in blended learning against their beliefs about the design of blended learning for addressing student diversity. Overall, there seems to be a trend toward more deliberate design of blended learning for instructors possessing a more extensive repertoire of strategies for differentiated instruction. However, this finding does not apply to all instructors. For example, even though instructor A9 reported more strategies for differentiated instruction than the average, she still held a disregard profile. The opposite also occurred, as instructors A13 and A15 indicated fewer strategies for differentiated instruction than the average, but actually hold a transformation profile. Further analyses suggest that these unexpected differences are the result of organizational factors. 


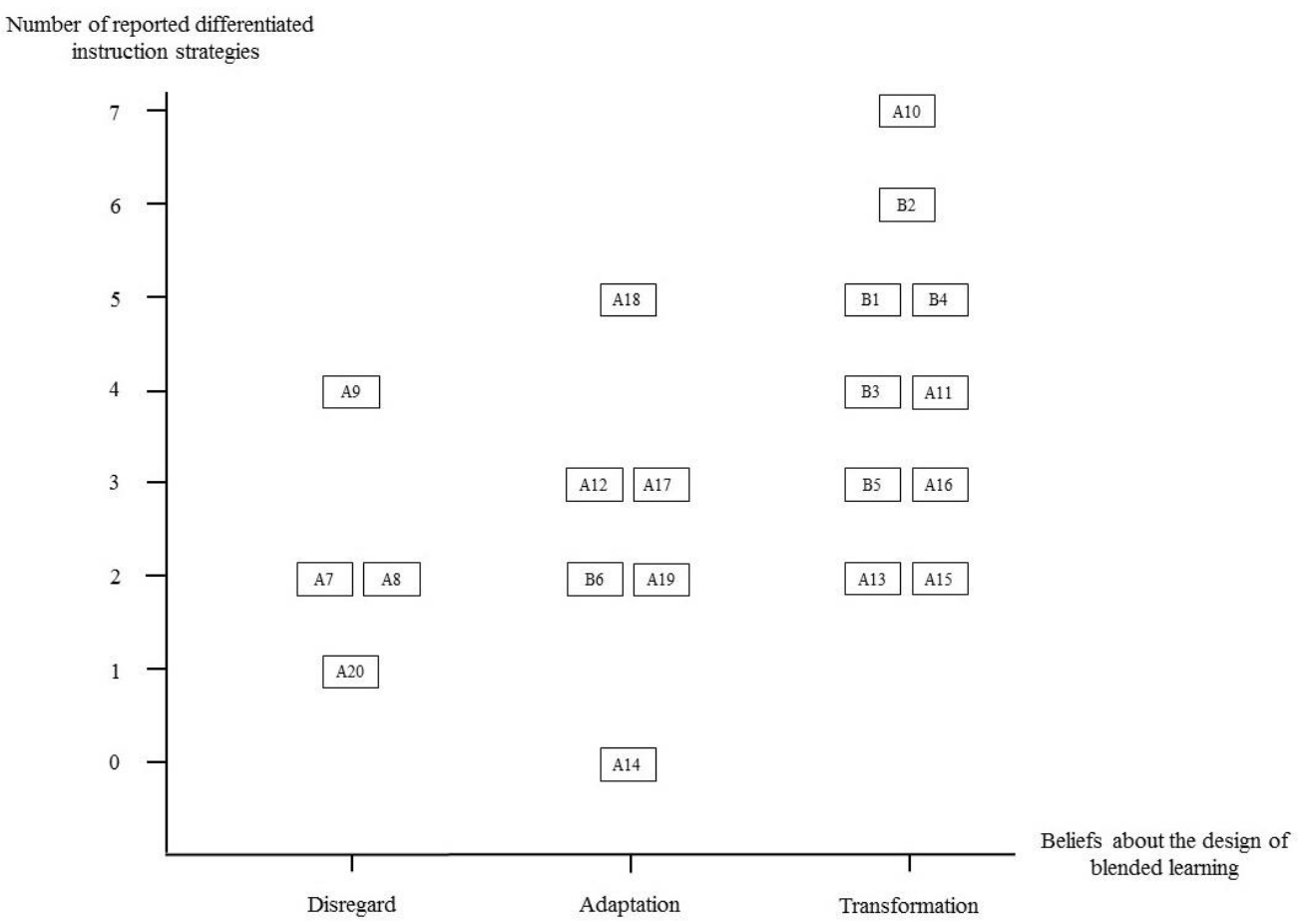

Figure 1. Relation between instructors' repertoire of strategies for differentiated instruction in blended learning and their beliefs about the design of blended learning for addressing student diversity.

Note. Every numbered symbol (1-20) represents an instructor, and the letter (A-B) refers to the center where they work.

Figure 2 adds the organization in which the instructors work into the equation. For instructors working in center A, it also indicates in which specific trajectory the instructors work. Since there were some instructors rather new to the e-learning trajectory, a distinction was made between instructors with less than one year of experience and instructors with more than one year of experience in the e-learning trajectory. Looking at instructors' use of differentiated instruction strategies, the average number of reported strategies in center $\mathrm{B}(\mathrm{M}=4.17, \mathrm{SD}=1.47)$ was higher than that in center $\mathrm{A}(\mathrm{M}=2.86, \mathrm{SD}=1.75)$. Figure 2 further shows that the center in which instructors worked, seemed also strongly connected to their beliefs about the design of blended learning to address student diversity. In line with their more extensive repertoire of differentiated instruction strategies, instructors in center B also advocate a more deliberate design of blended learning for addressing student diversity, compared to many of the instructors working in center A. To be more specific, five of the six instructors working in center B were identified as holding a transformation profile, and consequently believe that, to match the needs of students with a degree of technical or vocational secondary education in blended learning arrangements, 
not only additional support, but also a redesign of learning arrangements was needed. In center A, instructors' beliefs seemed to be associated with the trajectory in which they worked (for more information on these trajectories, see section 3.1 research setting). There appears to be a trend toward a more deliberate design, described here as a transformation profile, for instructors working already more than one year in the e-learning trajectory, while instructors working in the modular or non-modular trajectory often held a disregard or adaptation profile.

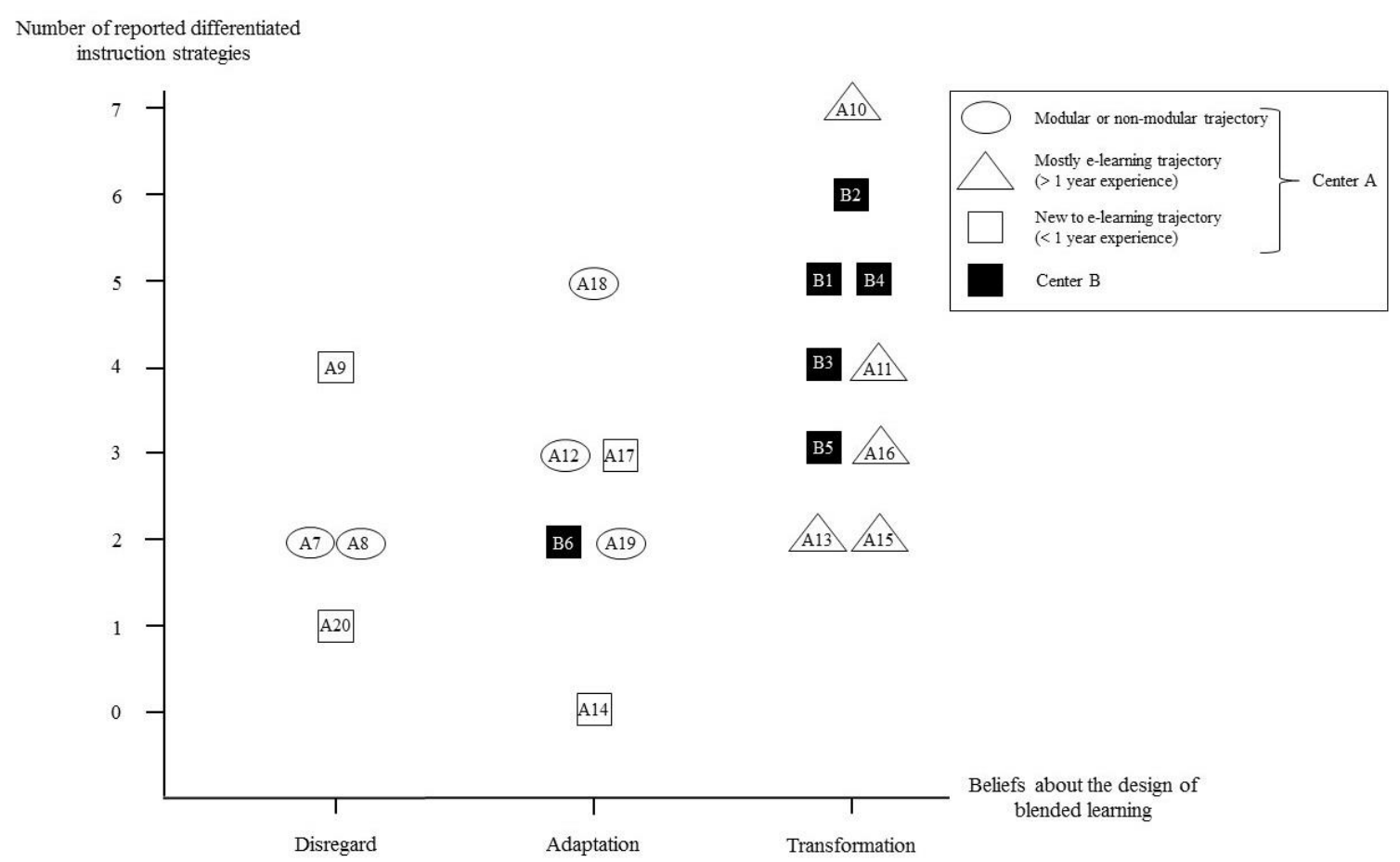

Figure 2. Relation between instructors' repertoire of strategies for differentiated instruction in blended learning and their beliefs about the design of blended learning for addressing student diversity.

Note. Every numbered symbol (1-20) represents an instructor, and the letter (A-B) refers to the center where they work. For more information on the trajectories in center A, see section 3.1 research setting.

\section{Discussion}

\subsection{Summary of findings and discussion}

In this section, we highlight the three major findings from our study: (1) some strategies for differentiated instruction were mentioned more than others, (2) half of the instructors considered a transformation of the blended learning arrangements, while the other half considered no or limited 
changes to existing blended learning arrangements, and (3) the organization appeared to be connected to instructors' views and use of differentiated instruction in blended learning.

\subsubsection{Strategies for differentiated instruction}

A first major finding is that some strategies for differentiated instruction are mentioned more frequently than others. Previous research identified four main categories of differentiated instruction, respectively focusing on: (1) content, or the information and ideas that students need to acquire to reach learning, (2) process, or how students process the content and acquire new skills, (3) product, or how students demonstrate what they have learned, and (4) affect, or how students feel about the classroom environment (Tomlinson, 2001; Tomlinson \& Imbeau, 2013). The findings of the present study point out that instructors more often put forward adjustments to the product and process level, than to the content or affect level. A likely explanation for these results may be that instructors are more familiar with strategies related to the product and process level, or that these strategies are easier to organize than differentiation at the content and affect level. When looking at specific strategies, the results reveal a number of differences compared to previous research. For instance, instructors in the present study frequently mentioned the importance of adequate assistance throughout product development, while earlier studies report that there is usually less attention to this strategy for differentiated instruction (Smit \& Humpert, 2012). Likewise, flexible grouping methods are hardly reported by the instructors in this study, while Humphrey et al. (2006) found that group work was often used by instructors to organize responsive teaching. A possible explanation for these differences is that the previous studies were situated in a more traditional context, whereas the present study is situated in a blended learning context. It might be easier to organize formative assessments in the latter, as learning platforms can provide the instructor with additional opportunities to provide (automated) feedback to students (see e.g., Boelens, De Wever, \& Voet, 2017; McKenzie et al., 2013), while, on the other hand, the online component might be less suited to group work, since interaction and dialogue are easier to arrange in face-to-face meetings (Kember, McNaught, Chong, Lam, \& Cheng, 2010). 


\subsubsection{Beliefs about designing blended learning to address student diversity}

A second major finding is the typology of beliefs about designing blended learning to address student diversity, which emerged from the data. In particular, three profiles were discovered: a disregard, an adaptation, and a transformation profile. Instructors with a disregard profile either thought that additional support was not necessary, or did not seem to consider such support, even though they were aware of possible challenges to some students. For instructors with an adaptation profile, the proposed support remained limited to adjustments to existing learning arrangements. Instructors with a transformation profile believed that blended learning arrangements should be designed in a completely different way, and be tailored to the characteristics of the specific student group. This typology is consistent with other studies, indicating that not all instructors think about the design of blended learning arrangements in the same way (Bliuc et al., 2012; Ellis et al., 2009). However, it also nuances previous studies (e.g., Bliuc et al., 2012) which have considered tailored instruction in blended learning as a onedimensional concept, rather than considering gradations in its execution.

Looking at the results, it becomes clear that half of the instructors had a transformation profile, while the other half had either a disregard or an adaptation profile. On the one hand, this finding echoes that of previous studies, which have noted that most instructors are led by practical considerations when designing blended learning, and pay limited attention to individual students' needs (Bliuc et al., 2012; Davies et al., 2013; Ellis et al., 2009; C. Kim et al., 2013). On the other hand, it also indicates that a relatively large number of instructors are already particularly attentive to differences between students in their design of blended learning. While the findings clearly distinguish three types of instructors regarding their beliefs on how blended learning should be designed in response to student diversity, it is less clear how these differences can be explained.

\subsubsection{Explaining differences between instructors}

A third major finding is that the organization and trajectory in which instructors work seem to be associated with their repertoire of differentiated instruction strategies and most of the differences in their beliefs about designing blended learning to address student diversity. The results indicate that, in line 
with their more extensive repertoire of differentiated instruction strategies, most instructors of center B advocate a more deliberate design of blended learning, compared to many of the instructors in center A. Previous research suggests that this is likely the result of a clear stance of the organization with respect to differentiated instruction in a blended learning context (González, 2012). This is illustrated by the way differentiated instruction is handled at the institutional level, with students in center B being grouped based on their educational degree, whereas center A does not group students based on their educational background. As previous research has also shown, a clear and supportive strategy and vision in the organization has an impact on the decisions that individual instructors make (De Neve et al., 2015; González, 2012; Smith, 2011).

The results further reveal that instructors' beliefs about the design of blended learning in response to student diversity may also vary within an organization, depending on the specific trajectories in which they work. The results from center A show that instructors who are responsible for a trajectory with mainly online activities, are more likely to say that a redesign of the blended learning arrangements is needed from the ground up (i.e., transformation profile), while instructors who are responsible for a trajectory with more face-to-face meetings or who just started teaching in a trajectory with mainly online activities are more likely to say that adjustments to the existing blended learning arrangements are sufficient (i.e., adaptation profile). There are two plausible explanations for these different types of instructor beliefs within the organization.

The first is that there may exist several subcultures in the organization, related to the specific trajectory in which instructors work. This may explain why most instructors in the e-learning trajectory had a transformation profile, whereas those in other trajectories had an adaptation or disregard profile. This could also explain why instructors with less than one year of experience in the e-learning trajectory did not have a transformation profile, as they likely need more time to adopt the organizational subculture and establish shared views with colleagues.

The second possible explanation is that the differences between trajectories may be due to the size of their online components. As the online activities provide increased autonomy for students, a certain amount of self-regulation is required (Barnard, Lan, To, Paton, \& Lai, 2009; Lynch \& Dembo, 2004). 
Previous research has shown that students without higher education degree may be less able to selfregulate their learning (Owston et al., 2013; Räisänen et al., 2016), and thus often encounter more difficulties in blended learning contexts. This was also indicated by the instructors in the present study. With this in mind, it seems logical that instructors working in a trajectory with mainly online activities propose more profound changes in the way blended learning is designed for students without higher education degree.

\subsection{Limitations and suggestions for further research}

A first limitation of this study is that the small sample size limits the ability to generalize some of the results, such as the most frequently used strategies for differentiated instruction. Even though these results are useful indications, they have yet to be confirmed by more large-scale studies. Still, these results are not the only contribution that the present study offers to the field, as it also introduces a typology for beliefs about the design of blended learning for responding to student diversity, while also pointing out that the organization plays an important role in the development of these beliefs. A second limitation of this study is that the strategies for differentiated instruction of the instructors are based on self-reports, and there were no direct observations to assess the accuracy of these self-reports. However, using self-reports is a common approach in similar studies (e.g., De Neve et al., 2015), and previous research has demonstrated that self-reports are a valid way to measure instructional outcomes (Dumont \& Troelstrup, 1980). Still, future research could investigate whether observations and self-reports would also be similar in this particular case. Finally, a third limitation is that, although the findings suggest that the organization is related to the instructors' profile, the question remains whether tracking students at institutional level is the cause or the consequence of instructors' beliefs. As such, further research in organizations that are adopting blended learning could provide more insight in this causality.

\subsection{Implications}


The present study explored instructors' strategies for differentiated instruction in blended learning and their beliefs about designing blended learning to address student diversity. To further investigate the differences between instructors, both were compared to one another, as well as the organization and trajectory in which they work. The results hold two important implications to both theory and practice.

First of all, the finding that half of the instructors believed that student diversity required no, or only limited, adaptations to their blended learning arrangements, suggests that professional support focusing on these beliefs is of crucial importance for instructors to unlock blended learning's full potential. In light of this, the present study's framework of strategies for differentiated instruction could be used as a starting point for expanding instructors' strategies for coping with student diversity in blended learning contexts. In addition, the three profiles concerning beliefs about developing blended learning arrangements to address student diversity can be used by organizations and instructors to reflect on their own practice, to become more aware of their own beliefs, and to adjust their teaching approach.

Second, differences in instructors' beliefs about the design of blended learning were, according to the present study, mainly attributable to the organizational level, or the center and trajectories where instructors work. As such, it is important for organizations to develop a clear stance on this issue, which pays explicit attention to proactively planning differentiated instruction and responding to students' needs in blended learning contexts. Recent work on institutional adoption (e.g., Graham, Woodfield, \& Harrison, 2013) could serve as a framework for this kind of endeavor. This is also an important issue for future research, which should investigate exactly how organizations can contribute to the development of instructors' beliefs about the design of blended learning to address student diversity. A possible starting point for such research can be found in the literature on differentiated instruction, which suggests that organizations should create a collective responsibility, by offering opportunities for instructors to share knowledge, ideas, and experiences, to enhance professional learning related to differentiated instruction (De Neve et al., 2015; Smith, 2011). 


\section{References}

Barnard, L., Lan, W. Y., To, Y. M., Paton, V. O., \& Lai, S.-L. (2009). Measuring self-regulation in online and blended learning environments. The Internet and Higher Education, 12(1), 1-6. http://doi.org/10.1016/j.iheduc.2008.10.005

Bliuc, A.-M., Casey, G., Bachfischer, A., Goodyear, P., \& Ellis, R. A. (2012). Blended learning in vocational education: teachers' conceptions of blended learning and their approaches to teaching and design. The Australian Educational Researcher, 39(2), 237-257. http://doi.org/10.1007/s13384-012-0053-0

Boelens, R., De Wever, B., \& Voet, M. (2017). Four key challenges to the design of blended learning: A systematic literature review. Educational Review Research, 22, 1-18. http://doi.org/10.1016/j.edurev.2017.06.001

Boelens, R., Van Laer, S., De Wever, B., \& Elen, J. (2015). Blended learning in adult education: towards a definition of blended learning. Adult Learners Online! Blended and Online Learning in Adult Education and Training. Retrieved from http://www.iwt-alo.be/wpcontent/uploads/2015/08/01-Project-report-Blended-learning-in-adult-education-towards-adefinition-of-blended-learning.pdf

Cohen, L., Manion, L., \& Morrison, K. (2007). Research Methods in Education (Sixth edit). London and New York: Routledge. http://doi.org/10.1111/j.1467-8527.2007.00388_4.x

Davies, R. S., Dean, D. L., \& Ball, N. (2013). Flipping the classroom and instructional technology integration in a college-level information systems spreadsheet course. Educational Technology Research and Development, 61(4), 563-580. http://doi.org/10.1007/s11423-013-9305-6

De Neve, D., Devos, G., \& Tuytens, M. (2015). The importance of job resources and self-efficacy for beginning teachers' professional learning in differentiated instruction. Teaching and Teacher Education, 47, 30-41. http://doi.org/10.1016/j.tate.2014.12.003

Dumont, R. G., \& Troelstrup, R. L. (1980). Exploring Relationships between Objective and Subjective Measures of Instructional Outcomes. Research in Higher Education, 12(1), 37-51.

Ellis, R. A., Hughes, J., Weyers, M., \& Riding, P. (2009). University teacher approaches to design and teaching and concepts of learning technologies. Teaching and Teacher Education, 25(1), 109-117. http://doi.org/10.1016/j.tate.2008.06.010

Ertmer, P. A. (2005). Teacher pedagogical beliefs: The final frontier in our quest for technology integration? Educational Technology Research and Development, 53(4), 25-39. http://doi.org/10.1007/BF02504683

Eurydice. (2009). Educational structures and education systems for vocational training and adult education in Europe. Belgium, Flemish Community. Vlaamse overheid.

Fry, H., Ketteridge, S., \& Marshall, S. (2008). A handbook for teaching and learning in higher education: enhancing academic practice. (H. Fry, S. Ketteridge, \& S. Marshall, Eds.) (Third edit). New York and London: Routledge. Retrieved from https://books.google.be/books?id=5Rp9AgAAQBAJ\&printsec=frontcover\&hl=nl\&source=gbs_g e_summary_r\&cad $=0 \# v=$ onepage $\& \mathrm{q} \& \mathrm{f}=$ false

González, C. (2012). The relationship between approaches to teaching, approaches to e-teaching and perceptions of the teaching situation in relation to e-learning among higher education teachers. Instructional Science, 40(6), 975-998. http://doi.org/10.1007/s11251-011-9198-x 
Goodman, J. (1988). Constructing a practical philosophy of teaching: A study of preservice teachers' professional perspectives. Teaching and Teacher Education, 4(2), 121-137. http://doi.org/10.1016/0742-051X(88)90013-3

Graham, C. R., Woodfield, W., \& Harrison, J. B. (2013). A framework for institutional adoption and implementation of blended learning in higher education. The Internet and Higher Education, 18, 4-14. http://doi.org/10.1016/j.iheduc.2012.09.003

Hall, B. T., Strangman, N., \& Meyer, A. (2003). Differentiated instruction and implications for UDL implementation. Effective Classroom Practices Report. National Center on Accessing the General Curriculum.

Humphrey, N., Bartolo, P., Ale, P., Calleja, C., Hofsaess, T., Janikova, V., ... Wetso, G. (2006). Understanding and responding to diversity in the primary classroom: an international study. European Journal of Teacher Education, 29(3), 305-318. http://doi.org/10.1080/02619760600795122

Kagan, D. M. (1992). Implications of research on teacher belief. Educational Psychologist, 27(1), 6590.

Kember, D., McNaught, C., Chong, F. C. Y., Lam, P., \& Cheng, K. F. (2010). Understanding the ways in which design features of educational websites impact upon student learning outcomes in blended learning environments. Computers \& Education, 55(3), 1183-1192. http://doi.org/10.1016/j.compedu.2010.05.015

Kim, C., Kim, M. K., Lee, C., Spector, J. M., \& DeMeester, K. (2013). Teacher beliefs and technology integration. Teaching and Teacher Education, 29, 76-85. http://doi.org/10.1016/j.tate.2012.08.005

Kim, M. K., Kim, S. M., Khera, O., \& Getman, J. (2014). The experience of three flipped classrooms in an urban university: an exploration of design principles. The Internet and Higher Education, 22, 37-50. http://doi.org/10.1016/j.iheduc.2014.04.003

Klug, J., Krause, N., Schober, B., Finsterwald, M., \& Spiel, C. (2014). How do teachers promote their students' lifelong learning in class? Development and first application of the LLL Interview. Teaching and Teacher Education, 37, 119-129. http://doi.org/10.1016/j.tate.2013.09.004

Lawrence-Brown, D. (2004). Differentiated Instruction: Inclusive Strategies for Standards -Based Learning That Benefit the Whole Class. American Secondary Education, 32(3), 34-63.

Lynch, R., \& Dembo, M. (2004). The Relationship between Self-Regulation and Online Learning in a Blended Learning Context. International Review of Research in Open and Distance Learning, 5(2), 1-16. Retrieved from http://www.irrodl.org/index.php/irrodl/article/view/189/799

McDonald, P. L. (2014). Variation in Adult Learners' Experiences of Blended Learning in Higher Education. In A. G. Picciano, C. D. Dziuban, \& C. R. Graham (Eds.), Blended Learning: Research Perspectives (Volume 2, pp. 215-234). New York: Routledge.

McKenzie, W. A., Perini, E., Rohlf, V., Toukhsati, S., Conduit, R., \& Sanson, G. (2013). A blended learning lecture delivery model for large and diverse undergraduate cohorts. Computers \& Education, 64, 116-126. http://doi.org/10.1016/j.compedu.2013.01.009

Miles, M. B., \& Huberman, M. A. (1994). Qualitative data analysis: An expanded sourcebook (2nd ed.). London: Sage.

Nicolae, M. (2014). Teachers' Beliefs as the Differentiated Instruction Starting Point: Research Basis. Procedia - Social and Behavioral Sciences, 128, 426-431. http://doi.org/10.1016/j.sbspro.2014.03.182

Norberg, A., Dziuban, C. D., \& Moskal, P. D. (2011). A time-based blended learning model. On the Horizon, 19, 207-216. http://doi.org/10.1108/10748121111163913 
Owston, R., York, D., \& Murtha, S. (2013). Student perceptions and achievement in a university blended learning strategic initiative. The Internet and Higher Education, 18, 38-46. http://doi.org/10.1016/j.iheduc.2012.12.003

Pajares, M. F. (1992). Teachers' Beliefs and Educational Research: Cleaning Up a Messy Construct. Review of Educational Research, 62, 307-332.

Räisänen, M., Postareff, L., \& Lindblom-Ylänne, S. (2016). University students' self- and co-regulation of learning and processes of understanding: A person-oriented approach. Learning and Individual Differences, 47, 281-288. http://doi.org/10.1016/j.lindif.2016.01.006

Ruys, I., Defruyt, S., Rots, I., \& Aelterman, A. (2013). Differentiated instruction in teacher education: A case study of congruent teaching. Teachers and Teaching, 19(1), 93-107. http://doi.org/10.1080/13540602.2013.744201

Santangelo, T., \& Tomlinson, C. A. (2009). The application of differentiated instruction in postsecondary environments: Benefits, challenges, and future directions. International Journal of Teaching and Learning in Higher Education, 20(3), 307-323.

Smit, R., \& Humpert, W. (2012). Differentiated instruction in small schools. Teaching and Teacher Education, 28(8), 1152-1162. http://doi.org/10.1016/j.tate.2012.07.003

Smith, J. C. (2011). Differentiated instruction: exploring implementation at the middle level. University of Colorado.

Tomlinson, C. A. (2001). How to differentiate instruction in mixed-ability classrooms (2nd ed.). Alexandria, Virginia: Association for Supervision and Curriculum Development.

Tomlinson, C. A., Brighton, C., Hertberg, H., Callahan, C. M., Moon, T. R., Brimijoin, K., ... Reynolds, T. (2003). Differentiating instruction in response to student readiness, interest, and learning profile in academically diverse classrooms: A review of literature. Journal for the Education of the Gifted, 27(2), 119-145. http://doi.org/10.1177/016235320302700203

Tomlinson, C. A., \& Imbeau, M. B. (2013). Differentiated instruction. In B. J. Irby, G. Brown, R. LaraAlecia, \& S. Jackson (Eds.), The Handbook of Educational Theories (pp. 1097-1117). Charlotte, North Carolina: Information Age Publishing, Inc.

Tomlinson, C. A., \& Kalbfleisch, M. L. (1998). Teach Me, Teach My Brain: A Call for Differentiated Classrooms. Educational Leadership. Retrieved from http://web.ebscohost.com.ezproxy.mtsu.edu/ehost/pdfviewer/pdfviewer?sid=dc1003de-78b24562-9f4f-

86a591997879\%40sessionmgr12\&vid=11\&hid=21\%5Cnhttp://www.eric.ed.gov/ERICWebPorta 1/recordDetail?accno $=$ EJ575232

Valcke, M., Sang, G., Rots, I., \& Hermans, R. (2010). Taking prospective teachers' beliefs into account in teacher education. International Encyclopedia of Education, 7, 622-628. http://doi.org/10.1016/B978-0-08-044894-7.00668-0

Vasileva-Stojanovska, T., Malinovski, T., Vasileva, M., Jovevski, D., \& Trajkovik, V. (2015). Impact of satisfaction, personality and learning style on educational outcomes in a blended learning environment. Learning and Individual Differences, 38, 127-135. http://doi.org/10.1016/j.lindif.2015.01.018

Voet, M., \& De Wever, B. (2016a). History teachers' conceptions of inquiry-based learning, beliefs about the nature of history, and their relation to the classroom context. Teaching and Teacher Education, 55, 57-67. http://doi.org/10.1016/j.tate.2015.12.008

Voet, M., \& De Wever, B. (2016b). Towards a differentiated and domain-specific view of educational technology: An exploratory study of history teachers' technology use. British Journal of Educational Technology. http://doi.org/10.1111/bjet.12493 
Wanner, T., \& Palmer, E. (2015). Personalising learning: exploring student and teacher perceptions about flexible learning and assessment in a flipped university course. Computers \& Education, 88, 354-369. http://doi.org/10.1016/j.compedu.2015.07.008

Watson, J. (2008). Blended Learning: The Convergence of Online and Face-to-Face Education. Promising practices in online learning (Vol. 572). North American Council for Online Learning. Retrieved from https://goo.gl/6AGpNP 


\section{Appendix A: Interview protocol}

\section{Introduction}

- Thank the participant for participating in the study

- Explain the goals of the study: investigate instructors' experiences in working with and responding to student diversity (and more specific: students with a degree of vocational or technical secondary educations versus students with a degree of higher education), and perceived challenges when designing blended learning arrangements in general and with respect to learner diversity

- Explain the three parts of the interview

- Emphasize that the focus is on their experiences and opinions, and that there are no right or wrong answers

- Ask permission to record the interview, and explain that all data will be treated confidentially

- Sign informed consent

\section{Background information}

- What is your year of birth?

- What higher education program did you follow?

- Can you provide a description of your career?

- How long have you been teaching in this center for adult education?

○ In which programs or trajectories do you currently teach?

○ Which courses/subjects do you teach?

- How long have you been teaching these courses/subjects?

- Have you been enrolled in a blended learning course as a student?

- If yes, in which program(s) or course(s)?

○ How much experience do you have with blended/distance learning? (one lesson, an entire course,...)

$\circ$ What are your experiences? Both positive and negative?

- Do you have experience with blended/distance learning as an instructor?

$\circ \quad$ If yes, in which program(s) or course(s)?

○ How much experience do you have with blended/distance learning? (one lesson, whole course,,..$)$

○ What are your experiences? Both positive and negative?

\section{Experiences in working with and responding to student diversity}

What are, according to you, the most important differences between students with a degree of vocational or technical secondary education and students with a degree of higher education? (open question) 
- For every difference:

- Can you provide a concrete example?

$\circ$ How is this related to your teaching? How do you cope with these differences during your lessons?

- When instructors have responded to the question, prompts were provided about the themes that were not spontaneously discussed during the open question (to stimulate the discussion, based on literature). Again, when participants further discussed about a theme, they were asked to provide a concrete example and how this was related to their teaching.

- Do you see differences with respect to students'...

- self-efficacy, that students feel confident in solving tasks and to believe in their own abilities (Klug, Krause, Schober, Finsterwald, \& Spiel, 2014)

- planning skills, or how students plan their own learning activities? (Klug et al., 2014)

- use of study methods and learning strategies? (Klug et al., 2014)

- self-reflection, as students' ability to monitor and evaluate their own learning process (Klug et al., 2014)

- reasoning/attribution, as to which reasons students assume led to their performance? (Klug et al., 2014)

- ICT skills or ICT competencies?

- motivation?

- feelings about the classroom environment, as students feel safe in the learning environment?

- attitude toward education?

- attitude toward peers?

- prior knowledge?

- sense of belonging, relation with other students in the group? (McDonald, 2014)

- relation and attitude toward the instructor (McDonald, 2014)

- written language skills

- oral language skills

4. Beliefs and perceptions about the design of blended learning arrangements in general, and with respect to learner diversity

\section{In general}

- How does the distance/online learning take part in your lessons?

- Which learning activities are expected of students? 
○ How do you provide support to students during the online or distance part? E.g., can students reach you by email?

- How is the online part connected to the face-to-face meetings?

- Are there certain skills necessary to successfully complete a blended learning course or program? (based on McDonald, 2014)

- What can we, according to you, achieve with the concept blended learning? What is the power of blended learning?

- What can we certainly not achieve with the concept blended learning?

- What are the most essential components in a blended learning arrangement? What advice would you give to design an effective blended learning arrangement?

$\underline{\text { Students with a degree of vocational or technical secondary education }}$

- Do students with a degree of vocational or technical secondary education encounter challenges during blended learning courses or problems to successfully complete a blended learning course? If yes, what are these challenges? Provide a concrete example.

- What do you want to change, or what needs to be modified to overcome these challenges or problems?

- With regard to students with a degree of vocational or technical secondary education: what is going well in the blended learning arrangements?

- To summarize, can you indicate what components should be emphasized to design a suitable blended learning arrangement for this target group?

\section{End}

- Ask whether the instructor has additional comments related to the themes of the interview

- Thank the participant for participating in the study 


\section{Appendix B: coding scheme}

DIFF: strategies that adult educators put forward to differentiate between students with a degree of (a) vocational or technical secondary education and (b) higher education

\begin{tabular}{|c|c|c|c|c|}
\hline \multicolumn{2}{|c|}{$\begin{array}{l}\text { Instructors can differentiate } \\
\text { instruction through... } \\
\text { (Tomlinson \& Imbeau, 2013) }\end{array}$} & \multicolumn{2}{|c|}{$\begin{array}{l}\text { Underlying categories and examples of strategies } \\
\text { Based on Lawrence-Brown (2004), Tomlinson \& Kalbfleisch (1998), Tomlinson et al. } \\
\text { (2003), Tomlinson (2001), Santangelo \& Tomlinson (2009) }\end{array}$} & Code \\
\hline \multirow[b]{3}{*}{ Content } & \multirow{3}{*}{$\begin{array}{l}\text { (1) What students learn } \\
\text { / what we teach } \\
\text { (curricula) } \\
\text { (2) How content is } \\
\text { presented to students: } \\
\text { resources and material } \\
\text { students need to use to } \\
\text { acquire the content and } \\
\text { reach the learning goals }\end{array}$} & \multicolumn{2}{|c|}{ Modify curricula (what we teach): match learning content to students' needs } & 01DIFF_Curriculum \\
\hline & & \multicolumn{2}{|c|}{$\begin{array}{l}\text { More varied lesson/instructional material, for example: } \\
\text { - match materials to the specific instructional needs of groups } \\
\text { - present information in varied ways: orally, visually, through demonstration, part to } \\
\text { whole, and whole to part } \\
\text { - provide text materials at varied reading levels and levels of complexity }\end{array}$} & 02DIFF_LessonMaterial \\
\hline & & \multicolumn{2}{|c|}{$\begin{array}{l}\text { Additional support, for example: } \\
\text { - provide advanced organisers, highlighted print materials, key ideas, visual aids, } \\
\text { outlines, summaries } \\
\text { - add structure } \\
\text { - provide connections with prior knowledge or experiences } \\
\text { - provide clear expectations and examples, using examples and illustrations that } \\
\text { represent varied ways of thinking, or clarify the final goals with examples of } \\
\text { successful work from other students }\end{array}$} & 03DIFF_ContentSupport \\
\hline $\begin{array}{l}\text { Process / } \\
\text { activity }\end{array}$ & $\begin{array}{l}\text { How students process } \\
\text { the content }\end{array}$ & $\begin{array}{l}\text { How the instructor } \\
\text { modifies his/her } \\
\text { teaching methods, } \\
\text { instructional strategies, } \\
\text { and learning activities } \\
\text { based on student } \\
\text { diversity. How he or she } \\
\text { applies the content. }\end{array}$ & $\begin{array}{l}\text { Whole class instruction, adjust teaching methods and } \\
\text { instructional strategies to the entire class. Flexibility in } \\
\text { whole class instruction can be achieved when students } \\
\text { are tracked in rather homogeneous class groups, or when } \\
\text { instructors carefully select instructional strategies that } \\
\text { attend to a specific group of students in the classroom } \\
\text { and which is in addition beneficial for all students }\end{array}$ & 04DIFF_WholeClass \\
\hline
\end{tabular}




\begin{tabular}{|c|c|c|c|c|}
\hline & & \multirow{2}{*}{$\begin{array}{l}\text { - different degrees of } \\
\text { difficulty, complexity, } \\
\text { or specificity } \\
\text { - varying the pace of } \\
\text { work } \\
\text { - connections between } \\
\text { learning activities and } \\
\text { personal interests }\end{array}$} & $\begin{array}{l}\text { (Flexible) grouping: use a variety of grouping strategies } \\
\text { to match students and tasks (mixed or similar } \\
\text { readiness/interests/learning profile) }\end{array}$ & 05DIFF_Grouping \\
\hline & & & $\begin{array}{l}\text { Individualized activities, for example: offer assignments } \\
\text { on the same topic at varying degrees of difficulty, let } \\
\text { students work at their own pace, give learners choices } \\
\text { about topics in which to specialize, give students choices } \\
\text { about ways of learning, provide additional instruction to } \\
\text { the individual student }\end{array}$ & 06DIFF_IndividAct \\
\hline \multirow{2}{*}{ Product } & \multirow{2}{*}{$\begin{array}{l}\text { How students } \\
\text { demonstrate what they } \\
\text { have learned (i.e., } \\
\text { know, understand, and } \\
\text { can do) at certain } \\
\text { points in a unit of study } \\
\text { (formative and } \\
\text { summative) }\end{array}$} & \multicolumn{2}{|c|}{$\begin{array}{l}\text { Provide additional support: adequate scaffolding and support throughout product } \\
\text { development. For example: } \\
\text { - additional feedback (during product development) } \\
\text { - divide assignments into smaller steps } \\
\text { - peer- and self-evaluation }\end{array}$} & 07DIFF_ProductSupport \\
\hline & & \multicolumn{2}{|c|}{$\begin{array}{l}\text { Provide varied assessment options, for example: } \\
\text { - portfolios, authentic problems to solve,... } \\
\text { - provide varied modes of expression (e.g., written paper vs oral presentation) to } \\
\text { show mastery of common learning goals } \\
\text { - give students choices about modes of expression }\end{array}$} & 08DIFF_Product_AssOp \\
\hline $\begin{array}{l}\text { Affect / } \\
\text { learning } \\
\text { environment }\end{array}$ & $\begin{array}{l}\text { The climate or tone of } \\
\text { the classroom. How } \\
\text { students feel about or } \\
\text { respond to learning and } \\
\text { the classroom } \\
\text { environment (students } \\
\text { feelings impact their } \\
\text { learning) }\end{array}$ & \multicolumn{2}{|c|}{$\begin{array}{l}\text { The instuctor stimulates... } \\
\text { - that everyone feels welcomed and contributes to everyone else feeling welcomed } \\
\text { - mutual respect, to accept and appreciate one another's similarities and differences } \\
\text { - that students feel safe in the classroom (students feel accepted and valued, students } \\
\text { dare to say they don't know or dare to make mistakes) } \\
\text { - every learner grow as much as he/she can in general ability and specific talents }\end{array}$} & 09DIFF_Affect \\
\hline \multicolumn{2}{|c|}{ Additional ICT support } & \multicolumn{2}{|c|}{$\begin{array}{l}\text { The instructor provides additional ICT support in and outside the classroom, e.g., } \\
\text { how to use the learning management system, or how to edit and format a Word } \\
\text { document }\end{array}$} & 10_DIFF_Ict \\
\hline
\end{tabular}


BLE: Adult educators' beliefs about designing blended learning arrangements for students with a degree of technical or vocational secondary education

- BLE_CHALL(SE): Perceived challenges that blended learning arrangements may pose for students with a degree of vocational or technical secondary education

- BLE_DEVEL(SE): Ways to design blended learning arrangements for students with a degree of vocational or technical secondary education to overcome these challenges

- This code consisted of three sub codes, derived from the data:

- Adaptation: Participants who believed that more and adapted guidance and support is necessary

- They indicate several actions to provide more guidance and support to students with a degree of vocational or technical secondary education, but did not explicitly stated that the whole design of a course or the learning activities should be changed or transformed

- Transformation: Participants who believed that the design of other blends or different learning arrangements is needed

- They indicate that the blend should not or cannot be the same for students with a degree of (a) vocational or technical secondary education, and (b) higher education. They propose to design different instructional activities or other kinds of blends

- Disregard: Participants with no clear beliefs about how to design blended learning arrangements for students with a degree of vocational or technical secondary education 